\title{
Systemic Weber-Christian disease
}

\author{
R. D. G. MILNER ${ }^{1}$ AND M. J. MITCHINSON \\ From Addenbrooke's Hospital, Cambridge, and the Department of Pathology, \\ University of Cambridge
}

SYNOPSIS A patient suffering from Weber-Christian panniculitis was found at necropsy to have similar lesions in the visceral adipose tissue. When the lesions occur internally, diagnosis during life is complicated by the difficulty of examining visceral adipose tissue and the disease may often go unrecognized, but patients suffering from Weber-Christian panniculitis should be investigated bearing in mind the possibility of internal lesions. Only 11 cases confirmed by necropsy appear to have been reported hitherto. The aetiology remains obscure. It is suggested that the name 'systemic WeberChristian disease' be applied when the lesions occur in adipose tissue other than the panniculus adiposus and that the term 'Weber-Christian panniculitis' be used when the lesions are confined to the subcutaneous adipose tissue.

Relapsing nodular febrile non-suppurative panniculitis was first described by Pfeifer (1892) but this name was not used until Weber (1925) and Christian (1928) reported cases; Brill (1936) introduced the eponym 'Weber-Christian disease'. Since then about a hundred cases have been reported but the aetiology remains obscure. The principal feature of the disease has been the appearance, often in women, of single or multiple subcutaneous nodules, sometimes tender, which after a few weeks or months may regress; in many cases further lesions have subsequently appeared elsewhere in the panniculus adiposus. Fever usually accompanies each crop of nodules. Histological examination shows inflammation and necrosis of the subcutaneous adipose tissue in the affected sites.

Eleven necropsies (Table) have been reported in which similar lesions were found in adipose tissue other than the panniculus adiposus. This paper describes a further case and compares it with those previously reported.

\section{CASE REPORT}

A 57-year-old white woman was first seen in November 1962 because of five painless subcutaneous nodules on her arm and thighs which had appeared nine months previously. The nodules were irregularly shaped, 1 to $6 \mathrm{~cm}$. in diameter, and tethered to the overlying skin which

'Now at the Institute of Child Health, Hammersmith Hospital, London, W.12.

Received for publication 25 June 1964. was discoloured reddish brown, but not to deep structures. She was otherwise well; a chest radiograph was normal. On 26 January 1963 she was admitted to hospital because of tiredness and loss of weight. Examination showed a small thin woman with a temperature of $103^{\circ} \mathrm{F}$. The nodules had become slightly smaller and less pigmented. The abdomen was distended and the liver palpable $8 \mathrm{~cm}$. below the costal margin. There were no other abnormal physical signs.

Laboratory investigations gave the following results :Haemoglobin was $10 \cdot 1 \mathrm{~g} . / 100 \mathrm{ml}$. (Haldane $14.8 \mathrm{~g} . / 100$ ml. $=100 \%$; W.B.C. $3,100 /$ c.mm.; M.C.H.C. $29 \cdot 1 \%$; E.S.R. $10 \mathrm{~mm}$./hour (Westergren); platelets 60,000/c.mm. Serum protein was $5.2 \mathrm{~g} . / 100 \mathrm{ml}$.; electrophoresis showed reduction in serum albumin. M.S.U. contained $50 \mathrm{mg} . /$ $100 \mathrm{ml}$. protein, 10 to 20 pus cells, and up to 10 red blood cells per high-power field; culture yielded a moderately heavy growth of coliform bacilli. A chest radiograph showed patchy shadowing in the mid and lower zones of the right lung and probably also in the left mid zone, with no evidence of significant mediastinal enlargement; it was thought that the changes could be the result of bronchopneumonia or of one or more forms of pulmonary infiltration. A biopsy of a nodule removed from the right thigh $(3.5 \times 1.8 \times 0.1 \mathrm{~cm}$. $)$ showed grey-white skin bearing a wedge of fatty tissue on its undersurface; on the cut surface there was a slight condensation of greywhite strands in the central part of the underlying adipose tissue. Histological examination (Dr. J. H. Rack): 'In the subcutaneous tissue there is a large and fairly well demarcated area of necrosis of fat. This is surrounded by chronic inflammatory cells, fibroblasts and young fibrous tissue. The inflammatory cells include lymphocytes, macrophages (many laden with lipid), small numbers of plasma cells, and occasional neutrophil leucocytes. Small vessels in the wall show intimal 
thickening which is attributable to the inflammation. One artery at a slight distance from the lesion shows medial hypertrophy and intimal proliferation but no evidence of acute inflammatory damage. Apart from perivascular inflammatory cellular infiltration and slight hyperkeratosis, the skin above this subcutaneous lesion appears normal. The appearances would do for "relapsing febrile nodular non-suppurative panniculitis" (Weber-Christian)'

During the following two weeks the patient became weaker, pyrexia was continuous, and the liver became larger and the abdomen more distended. A mass, thought to be the spleen, was palpated in the left hypochondrium. Serial radiographs showed increase in size of the pulmonary opacities, which later became confluent. On 6 February the laboratory findings were essentially unchanged apart from the haemoglobin which was now up to $11.8 \mathrm{~g} . / 100 \mathrm{ml}$; M.C.H.C. $28 \cdot 2 \%$, slight hypochromia, anisocytosis and slight macrocytosis; W.B.C. down to $2,300 /$ c.mm. The following additional estimations were performed: thymol turbidity was 1 unit (normal 0-4); zinc sulphate turbidity 3 units (normal 0-8); alkaline phosphatase $10 \mathrm{~K}$.-A. units (normal 3-11); serum bilirubin $0.5 \mathrm{mg} . \%$ (normal $0.1-0.8$ ); serum glutamic pyruvic transaminase 83 units (normal 5-30); serum amylase 250 Somogyi units (normal 60-160); serum lipase 1.7 Comfort units (normal 0-1-5). L.E. cells were not found in the blood on three occasions.

A week later the blood was examined serologically (Dr. P. J. Lachmann): 'Complement level normal; immunoconglutinin titre negative; L.E. cell test negative; immunoelectrophoretic pattern-no obvious abnormality; gamma globulin by zinc turbidity $45 \cdot 2$ turbidity units (normal 25-40). There is borderline hypergammaglobulinaemia, but no serological evidence to suggest systemic lupus erythematosus. Nuclear staining by fluorescent antibody technique was negative. However, bright staining of thyroid colloid and thyroid cell cytoplasm was present, findings that occur most often in Hashimoto's disease or idiopathic myxoedema.'

The patient was extremely ill and it was decided empirically to give prednisone, penicillin, and streptomycin (Fig. 1). Within 24 hours her condition improved dramatically and the fever and abdominal distension disappeared. It was then possible to determine that the left-sided abdominal mass was deep, rounded, firm and immobile, and it was thought to be either para-aortic lymph nodes or the left kidney. The liver had enlarged further.

Investigations on 13 February showed the haemoglobin to be 10 g. $/ 100 \mathrm{ml}$; M.C.H.C. $29.5 \%$; M.C.V. 125 c. $\mu$; R.B.C. 2.72 million/c.mm.; reticulocytes $0.7 \%$. On the following day a bone marrow specimen of good cellularity was obtained. Dr. D. G. Chalmers reported: 'Erythropoiesis is abnormal. There is some megaloblastic development with abnormal pyknosis and nuclear twinning. Myelopoiesis is normal. There are numbers of large cells present. Some of them conform to the appearance of reticulum cells, large with cloudy pale blue cytoplasm and a round, slightly eccentric fine chromatin nucleus with nucleoli. Others differ in that the nuclei are smaller, the chromatin condensed and the nucleoli are not obvious. The cytoplasm of these is foamy and occasionally fenestrated. These cells, however, form a very small part of the total number present. The marrow changes are reactive and do not reflect an uncomplicated megaloblastic anaemia'. On the same day a second biopsy from the left calf confirmed the original diagnosis of WeberChristian panniculitis.

After the patient had remained apyrexial for one week the laboratory investigations were repeated: the results were unchanged except that serum amylase was 140 Somogyi units (previously 250) and serum lipase 1.6 units (previously 1.7). The antibiotics were stopped but on the following day a temperature of $101^{\circ} \mathrm{F}$. developed and treatment was restarted. The fever did not abate and the antibiotic was changed to chloramphenicol. Intravenous pyelography on 21 February showed a normal right kidney and a non-functioning left kidney.

From this time onwards the patient gradually deteriorated. A left pleural effusion developed; on 15 March a pleural biopsy and cytological examination of the $1,800 \mathrm{ml}$. uniformly blood-stained aspirate revealed no evidence of infection but some large abnormal cells were suggestive of a malignant neoplasm. She became gradually weaker and died in coma on 22 March 1963, 13 months after the appearance of the subcutanecus nodules.

The clinical diagnosis was carcinoma of the left kidney with secondary carcinoma of the lungs; WeberChristian disease of the subcutaneous adipose tissue.

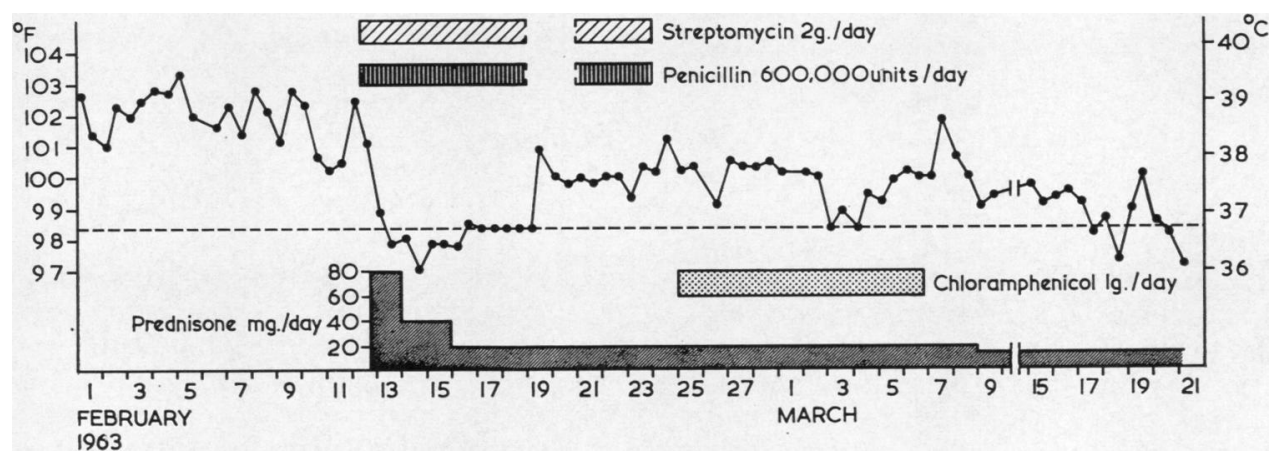

FIG. 1. Temperature and drug therapy during terminal illness. 
NECROPSY

At necropsy, performed six hours after death, the body was that of a middle-aged emaciated woman with rather atrophic skin, especially over the distended abdomen and the extremities. In the left popliteal fossa and on the medial side of the left upper arm near the axilla were two ill-defined bluish nodules, $3 \mathrm{~cm}$. in diameter (Fig. 2); they moved freely over the underlying tissue and were easily separated from the underlying muscle. On the left calf was a purple scar $3 \mathrm{~cm}$. long, and on the lateral aspect of the right

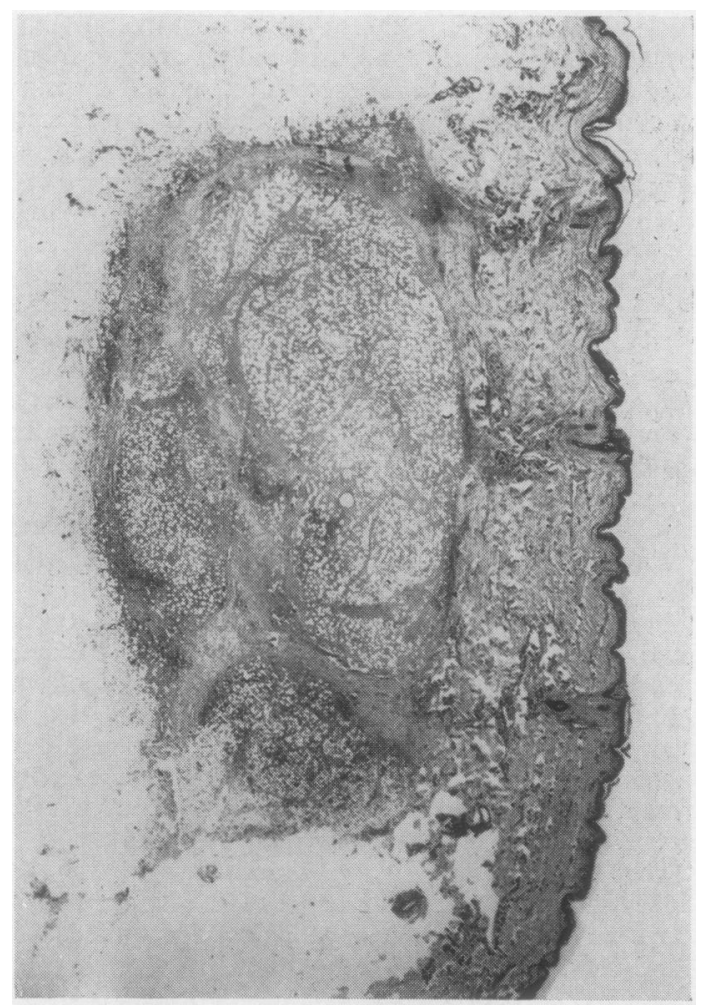

FIG. 2. Biopsy specimen of subcutaneous nodule showing typical Weber-Christian lesion. Haematoxylin and eosin $\times 7$.

thigh was an oval punched-out ulcer, $4 \times 2 \times 0.3$ $\mathrm{cm}$., with a red granulating floor and suture marks around it; these had been the sites of the two skin biopsies. There was bilateral oedema of the lower legs but no other external abnormality.

The abdominal cavity contained $1,600 \mathrm{ml}$. of slightly cloudy yellow fluid. The peritoneum covering the organs in the upper left quadrant of the abdomen was dull and pink. The gastrointestinal tract showed no significant abnormality except cholelithiasis, but the normal sized liver was yellowish and greasy on its cut surface. Both kidneys were of normal size and shape, but the left one was purple and completely surrounded by a broad shell of firm yellow-grey tissue which also enveloped the renal pedicle, the left suprarenal gland and nearby para-aortic lymph nodes and adhered to the tail of the pancreas (Fig. 3). The yellow-grey tissue also replaced the adipose tissue around the renal pelvis, infiltrating the renal medulla and inner cortex. It surrounded the proximal third of the thickened ureter and the ilio-psoas muscle which was expanded to twice its normal diameter by yellow-grey tissue separating the muscle bundles. The left renal vein contained two fragments of recent non-adherent antemortem thrombus.

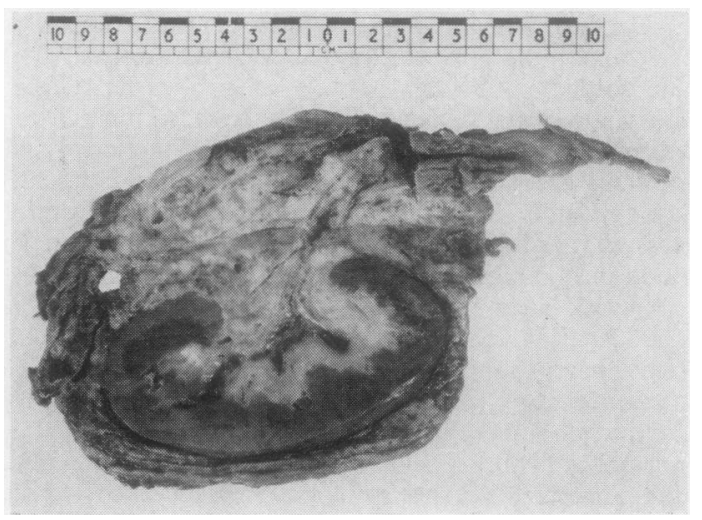

FIG. 3. Anterior half of left kidney and nearby tissues showing infiltration of peri-renal and peri-pelvic tissue, renal pedicle, medulla, and inner cortex by inflammatory process.

The slightly enlarged spleen was rather firm; the enlarged para-aortic lymph nodes showed a few grey-white markings on their purple cut surface suggestive of neoplastic invasion and some axillary and tracheo-bronchial lymph nodes had a similar appearance. The upper two-thirds of the shaft of the right femur contained red material.

The endocrine and genital organs showed no macroscopic abnormality except that the cut surface of the thyroid appeared fibrous.

The left pleural cavity contained $600 \mathrm{ml}$. of cloudy yellow-brown fluid and the right pleural cavity $100 \mathrm{ml}$. of clear yellow fluid. The left lower lobe was small and limp, suggesting collapse; all other lobes had a red cut surface and were apparently well aerated. There was fibrinous pleurisy of the left lower lobe, the inferior aspect of the left upper lobe, and the parietal pleura opposite the left lower lobe. Both lungs contained scattered 


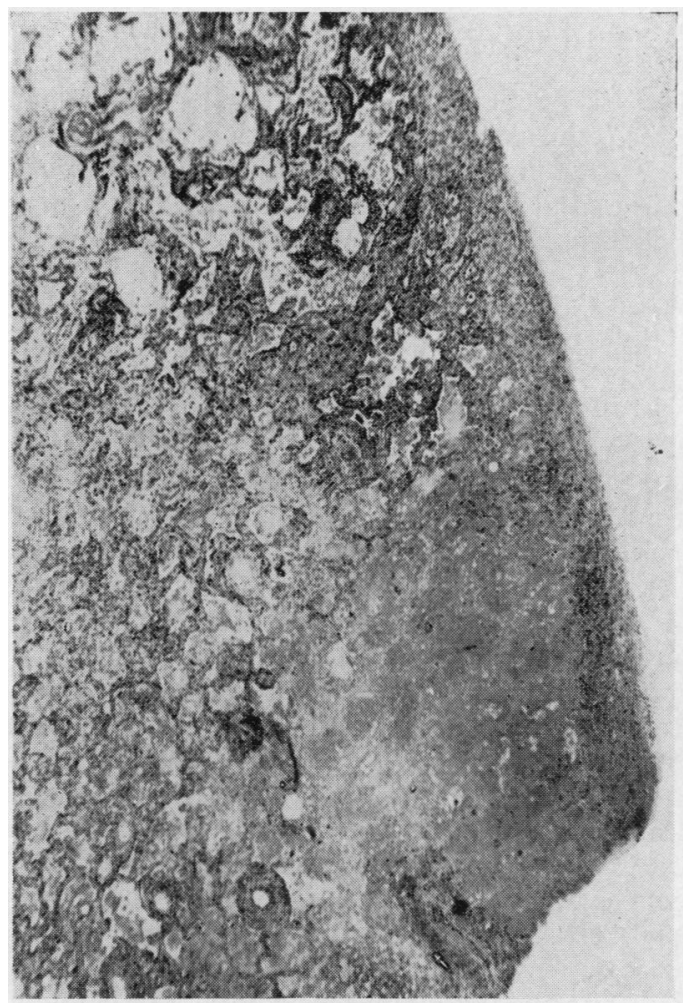

FIG. 4. One of the peripheral lung lesions. Haematoxylin and eosin $\times 16$.

peripheral firm nodules, up to $1 \mathrm{~cm}$. diameter, with a yellow-pink cut surface (Fig. 4).

In the cardiovascular system there was no significant abnormality except a slight degree of atherosclerosis. The foramen ovale was closed.

The brain and meninges were macroscopically normal. The spinal cord was not examined. No bacteriological investigation was made.

The macroscopic diagnosis was carcinoma of the left renal pelvis with secondary carcinoma of the lymph nodes, lungs, pleura, and organs around the left kidney: associated abnormalities were megaloblastic anaemia, renal vein thrombosis, and WeberChristian panniculitis.

\section{HISTOLOGICAL FINDINGS}

On histological examination there was no evidence of malignant disease. The mass in the left perirenal and extra-pelvic situations showed almost complete replacement of adipose tissue by eosinophilic amorphous material containing inflammatory cells (mainly pleomorphic histiocytes, many of bizarre shape, but also lymphocytes and a few polymorphonuclear

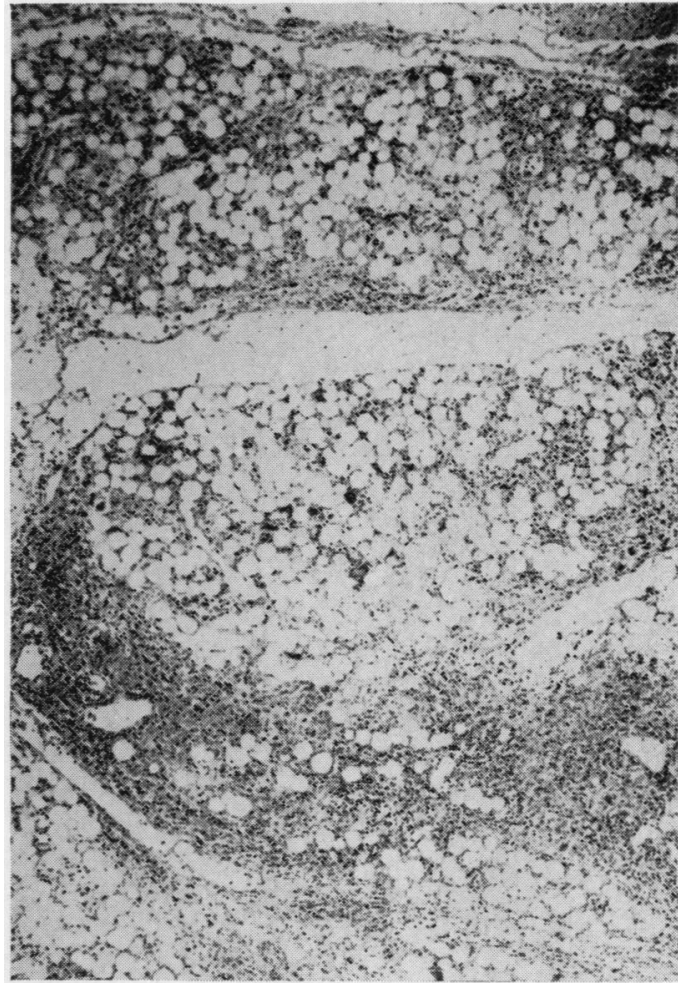

FIG. 5. Tissue surrounding left kidney showing adipose tissue infiltrated by inflammatory cells. Haematoxylin and eosin $\times 40$.

neutrophil leucocytes and plasma cells) and abundant nuclear debris (Fig. 5). There was very little fibrosis. The renal capsule separated the necrotic perirenal tissue from the renal cortex which showed no significant abnormality. In the extra-pelvic zone where the necrotic and inflammatory process encroached on renal tissue there was histiocytic and lymphocytic infiltration of perivascular connective tissue and inflammation and necrosis of tubules. Similar necrosis and inflammation extended into some neighbouring organs and tissues, namely, the ureter, lymph nodes, and autonomic ganglia, the psoas muscle, the right renal pedicle and extra-pelvic tissue, and one small area of the pancreas. The suprarenals and spleen were not invaded, although the tissue immediately outside the capsule of these organs was severely affected.

The histological appearance of necrosis and inflammation was similar to that of the subcutaneous nodules examined during life and after death. There was a conspicuous tendency to involvement of the interlobular and perivascular connective tissue with in a few places sparing of the centre of the adipose lobule. 


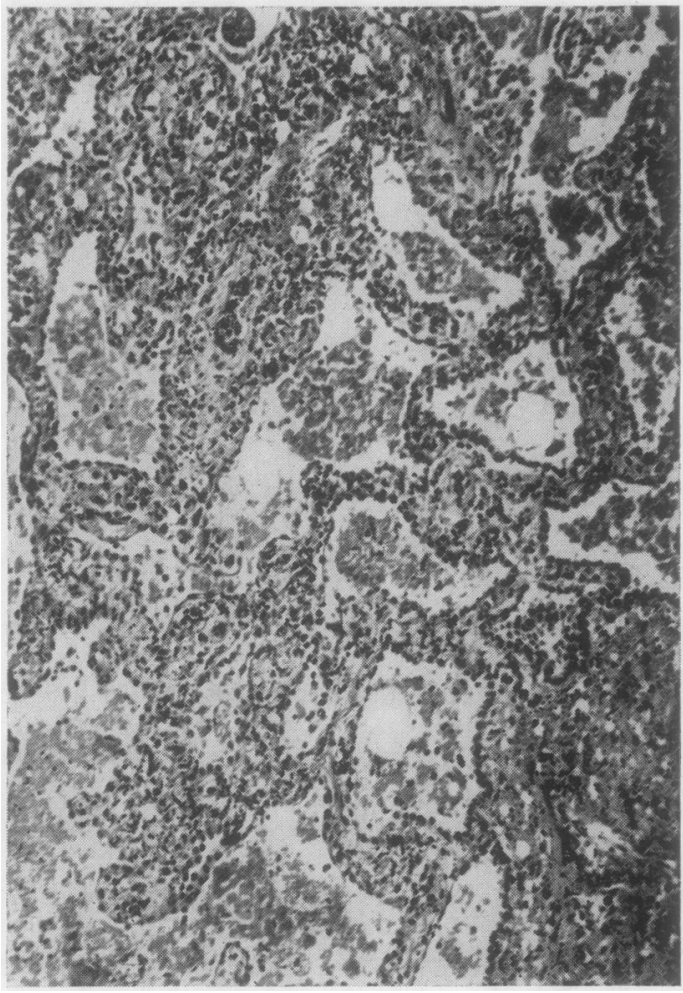

FIG. 6. Edge of lung lesion showing epithelialized alveoli filled by eosinophilic material and lipid. Haematoxylin and eosin $\times 100$.

The lung lesions were small recent peripheral areas of necrosis containing large numbers of free sudanophil globules; each lesion was bordered by partially epithelialized alveoli filled by eosinophilic material containing nuclear debris and large sudanophilic globules, both free and within macrophages (Fig. 6). The alveolar walls in these areas were thickened by similar material which was most abundant around small blood vessels. Many alveoli distant from the infarcts contained a crescentic layer of free fat and fat-filled macrophages; numerous capillaries in all lobes, but especially near the infarcts, contained globules of free fat.

The pleura covering the left lower lobe showed acute fibrinopurulent pleurisy and the peritoneum in the upper left quadrant of the abdomen showed acute fibrinopurulent peritonitis; both lesions contained large numbers of Gram-positive cocci, some arranged in chains. No organisms, including acidalcohol-fast bacilli, were seen in all the adipose tissue lesions after they had been specially stained.

The liver showed scattered areas of periportal fatty change but no evidence of necrosis, inflam- mation, or cirrhosis. The spleen contained an excess of plasma cells in the red pulp and a few macrophages containing sudanophil globules, immediately beneath the capsule. Sections of thyroid revealed an excess of fibrous tissue and lymphocytic foci such as are seen in 'chronic thyroiditis'. No significant abnormalities were found in sections of suprarenals, pituitary, parathyroid, cervix uteri, and jejunum. The sternum and femur sections showed no changes additional to those in the bone marrow report (see above).

In all the tissues where the necrosis and inflammation were present blood vessels, especially veins, were involved in a variable manner; sections showed necrosis and infiltration by inflammatory cells and nuclear debris resembling the infiltrate elsewhere. This was usually limited to the adventitia but often all coats were affected, sometimes segmentally. Many vessel walls contained sudanophil-laden cells, mainly intimal; some arteries showed sudanophil droplets in smooth muscle cells of the media. Thrombosis was frequent and widespread in affected vessels; often the lumen was filled by inflamed and necrotic tissue similar to that outside the vessel, and occasionally only a ring of elastin or collagen remained to show where a vessel had once presumably been. Vessels outside the lesions were not affected.

The final diagnosis was acute peritonitis and pleurisy and systemic Weber-Christian disease.

\section{DISCUSSION}

We apply the name 'systemic Weber-Christian disease' where the typical lesions occur in both visceral and subcutaneous adipose tissue, as in the above and the 11 cited examples (Table); we suggest the term 'Weber-Christian panniculitis' for cases in which the typical lesions are confined to the subcutaneous adipose tissue.

The diagnosis of Weber-Christian panniculitis is best confirmed by histological examination of a subcutaneous nodule, which shows pleomorphic inflammatory cellular infiltration of the subcutaneous adipose tissue and interlobular septa; the overlying dermis and epidermis are spared. The walls of small vessels are sometimes infiltrated by inflammatory cells or are necrotic. The infiltrate usually consists mainly of large mononuclear cells, including fatfilled macrophages, and sometimes giant cells. Polymorphonuclear leucocytes are not usually a conspicuous component except in the earliest stages (Ungar, 1946). Necrosis of local adipose tissue accompanies the inflammation and is usually followed by fibrous repair.

When the lesions occur internally diagnosis is more difficult because of the lack of opportunity to 
TABLE

DATA RELATING TO 11 REPORTED CASES OF SYSTEMIC WEBER-CHRISTIAN DISEASE EXAMINED BY NECROPSY

\begin{tabular}{|c|c|c|c|c|c|}
\hline \multirow[b]{2}{*}{ Author } & \multirow[b]{2}{*}{$\begin{array}{l}\text { Age, Sex, } \\
\text { Duration } \\
\text { of Illness }\end{array}$} & & \multirow[b]{2}{*}{ Other Findings } \\
\hline & & $\begin{array}{l}\text { Sites of Typical Lesions } \\
\text { in Internal Adipose Tissue }\end{array}$ & Liver Lesions & $\begin{array}{l}\text { Vascular } \\
\text { Lesions }\end{array}$ & \\
\hline Spain and Foley (1944) & $\begin{array}{l}51 \mathrm{M} \\
?\end{array}$ & $\begin{array}{l}\text { Retroperitoneal, } \\
\text { pretracheal }\end{array}$ & Fatty change & Absent & Fat necrosis of pancreas \\
\hline Ungar (1946) & $\begin{array}{l}37 \mathrm{~F} \\
9 \mathrm{mth} .\end{array}$ & $\begin{array}{l}\text { Retroperitoneal, } \\
\text { mediastinal, } \\
\text { pericardial }\end{array}$ & Fatty change & Slight & $\begin{array}{l}\text { Acute streptococcal peritonitis; } \\
\text { inferior vena caval thrombosis }\end{array}$ \\
\hline $\begin{array}{l}\text { Mostofi and Engleman } \\
\text { (1947) }\end{array}$ & $\begin{array}{l}38 \mathrm{M} \\
7 \mathrm{mth}\end{array}$ & $\begin{array}{l}\text { Retroperitoneal, } \\
\text { pericardial }\end{array}$ & $\begin{array}{l}\text { Fatty change, } \\
\text { patchy necrosis }\end{array}$ & Absent & $\begin{array}{l}\text { Pancreatic duct dilatation; } \\
\text { pleural effusions, lymphoid } \\
\text { hypoplasia and reticular } \\
\text { hyperplasia of spleen }\end{array}$ \\
\hline Steinberg (1953) & $\begin{array}{l}61 \mathrm{~F} \\
? 1 \frac{1}{2} \mathrm{yr} \text {. }\end{array}$ & $\begin{array}{l}\text { Retroperitoneal, } \\
\text { mediastinal, } \\
\text { pericardial, }\end{array}$ & $\begin{array}{l}\text { Vacuolated macrophages } \\
\text { in sinusoids }\end{array}$ & Absent & $\begin{array}{l}\text { Marrow and intestinal } \\
\text { submucosal lesions; lymphoid } \\
\text { hypoplasia of spleen }\end{array}$ \\
\hline & $\begin{array}{l}66 \mathrm{~F} \\
? 13 \mathrm{yr} \text {. }\end{array}$ & $\begin{array}{l}\text { Retroperitoneal, } \\
\text { myocardial }\end{array}$ & $\begin{array}{l}\text { Fatty change and focal } \\
\text { necrosis; fat-laden } \\
\text { macrophages in sinusoids }\end{array}$ & Present & $\begin{array}{l}\text { Lymphoid hypoplasia of spleen; } \\
\text { hyperplasia of reticulum cells, } \\
\text { fat-laden macrophages in spleen }\end{array}$ \\
\hline Ritama and Krusius (1953) & $\begin{array}{l}63 \mathrm{~F} \\
\text { Many } \\
\text { years }\end{array}$ & $\begin{array}{l}\text { Retroperitoneal, } \\
\text { mediastinal, } \\
\text { bladder neck }\end{array}$ & None & $\begin{array}{l}\text { Arterial } \\
\text { thrombi }\end{array}$ & \\
\hline Hutt and Pinniger (1956) & $\begin{array}{l}49 \mathrm{~F} \\
? 3 \mathrm{wk} \text {. }\end{array}$ & $\begin{array}{l}\text { Retroperitoneal, } \\
\text { pericardial extending into } \\
\text { myocardium }\end{array}$ & $\begin{array}{l}\text { Slight periportal } \\
\text { connective tissue increase }\end{array}$ & Present & $\begin{array}{l}\text { Bilateral suprarenal infarcts, } \\
\text { pleural effusions }\end{array}$ \\
\hline Fukuoka et al. (1957) & $\begin{array}{l}16 \mathrm{~F} \\
5 \mathrm{mth} .\end{array}$ & $\begin{array}{l}\text { Retroperitoneal, } \\
\text { pericardial }\end{array}$ & $\begin{array}{l}\text { Fatty change; foamy } \\
\text { macrophages in sinusoids } \\
\text { and Glisson's sheath }\end{array}$ & Doubtful & Foamy macrophages in marrow \\
\hline Schoen et al. (1958) & $\begin{array}{l}64 \mathrm{M} \\
2 \frac{1}{2} \mathrm{yr}\end{array}$ & Retroperitoneal & $\begin{array}{l}\text { Fatty change; mild portal } \\
\text { cirrhosis }\end{array}$ & Present & $\begin{array}{l}\text { Lung lesions; small fibrous } \\
\text { thyroid; lymphoid hypoplasia of } \\
\text { spleen }\end{array}$ \\
\hline $\begin{array}{l}\text { Nakagawa and } \\
\text { Takayanagi (1962) }\end{array}$ & $\begin{array}{l}26 \mathrm{~F} \\
4 \frac{1}{2} \mathrm{mth}\end{array}$ & $\begin{array}{l}\text { Retroperitoneal, } \\
\text { pericardial }\end{array}$ & $\begin{array}{l}\text { Fatty change; miliary } \\
\text { necrosis; hyperplasia of } \\
\text { Kupffer's cells }\end{array}$ & Present & $\begin{array}{l}\text { Lipophage infiltration of lung; } \\
\text { 'granulomas' of kidney; } \\
\text { hypoplasia of lymphoid tissue }\end{array}$ \\
\hline $\begin{array}{l}\text { Arnold and Bainborough } \\
\text { (1963) }\end{array}$ & $\begin{array}{l}72 \mathrm{M} \\
3 \mathrm{yr} .\end{array}$ & $\begin{array}{l}\text { Retroperitoneal, } \\
\text { mediastinal, pericardial } \\
\text { and within meningeal } \\
\text { lipoma }\end{array}$ & $\begin{array}{l}\text { Lipogranulomatosis } \\
\text { along the large vessels }\end{array}$ & Present & Lung lesions \\
\hline
\end{tabular}

examine visceral adipose tissue. In the present case the systemic nature of the disease was not recognized during life although the subcutaneous lesions were diagnosed as Weber-Christian panniculitis soon after the patient's admission to hospital.

The clinical presentation of systemic WeberChristian disease depends on the sites of the internal lesions. Anaemia of various types has been reported; infiltration of the bone marrow by lipid-filled macrophages has been described as a possibly related pathological finding (DeLor and Martz, 1955). Patchy shadowing in radiographs of the lungs has been reported only once previously (Schoen, Reingold, and Meister, 1958); in that case, as in the present one and in that of Arnold and Bainborough (1963), histological examination of the lung lesions revealed inflammation and necrosis similar to WeberChristian lesions elsewhere. Perforation of the bowel (Hutt and Pinniger, 1956; Schoen et al., 1958) has also been caused by systemic Weber-Christian disease. Usually, however, localizing clinical features do not arise until the systemic lesions are large and the patient first presents with subcutaneous lesions and malaise, abdominal discomfort, tiredness, or loss of weight.
Hepatomegaly, with or without splenomegaly, is a common finding but is also seen in some cases of Weber-Christian panniculitis (Hauge and Christiansen, 1954; case 2 of Hanrahan, Ippolito, and Dilworth, 1951). The pathological findings most often associated with systemic Weber-Christian disease are summarized in the Table. It seems likely that hepatomegaly and splenomegaly, like fat embolism to the lung (present case, and Miller and Kritzler, 1943), are manifestations of an increase of circulating lipid and lipid-filled macrophages, secondary to the breakdown of adipose tissue. We do not therefore consider that these secondary changes are manifestations of systemic WeberChristian disease when the typical lesions are restricted to the subcutaneous adipose tissue.

All 12 cases of systemic Weber-Christian disease have shown lesions in the subcutaneous adipose tissue, but this might not always be so. A close resemblance to the histological appearances of Weber-Christian disease is seen in isolated mesenteric lipodystrophy' (Crane, Aguilar, and Grimes, 1955; Rogers, Demetrakopoulos, and Hyamns, 1961 ; Herrington, Edwards, and Grossman, 1961) and in 'retractile mesenteritis' (Jura, 1924; Tedeschi and 
Botta, 1962). These may be interpreted as systemic Weber-Christian disease without panniculitis. In view of this possibility, it is interesting to consider that healed retroperitoneal systemic Weber-Christian disease might resemble idiopathic retroperitoneal fibrosis.

Of the many causative agents that have been suggested (Hallahan and Klein, 1951; Beerman, 1953; Steinberg, 1953) the present case seems to support best an auto-allergy or some other hypersensitivity phenomenon. Initially the recurrence of pyrexia after withdrawal of antibiotics suggested an infection, but recommencement and change of antibiotics had no effect on the fever, and the pleural aspirate and biopsy showed no evidence of infection. In view of the post-mortem histological findings, the pleurisy and peritonitis probably arose after the aspiration and the coccal illness, as in the cases of Ungar (1946) and Fukuoka, Ito, and Takeda (1957), was probably a terminal one. Post-mortem bacteriological studies were not undertaken but a careful search of the sections of the focal lung lesions and affected adipose tissue failed, as in previous cases, to support an infective origin for the disease; nevertheless, hypersensitivity to bacterial antigens remains a possible aetiological factor.

The administration of a corticoid may have been responsible for the fall in temperature and dramatic improvement in subjective wellbeing, but as in other cases (Macdonald, 1957; Kiernan and Burger, 1960; Hauge and Christiansen, 1954; Shuman, 1951) seemed to have no effect on the progress of the disease. Nevertheless auto-allergy remains a possible cause; direct investigation of this possibility (Ricci, Micheletti, and Coscia, 1961) has so far been inconclusive, as is the finding of auto-antibodies to thyroid colloid and thyroid cell cytoplasm in this case.

If the lesion is essentially one of adipose tissue, then the occurrence of deposits in non-fatty tissue such as lung suggests embolism. Thrombi were present in many veins in the affected internal adipose tissue; often the thrombi had been infiltrated by inflammatory cells. It is possible that these thrombi also contained the noxious agent, whatever it was. This case does not support an arterial cause for the lesions, as was suggested by Kennedy and Murphy (1949). Damaged vessels occurred only within lesions; the outer parts of larger vessels were more often and more severely involved than the inner parts; veins were as severely affected as arteries; except for those in the lung, the lesions did not correspond to arterial territories. The histological appearances would better support the following sequence of events: first, damage to adipose cells by the unknown agent or agents, causing inflammation and necrosis as a response to this damage. Extension of the inflammation, involving nearby tissues including blood vessels, may be followed by thrombosis of the affected vessels and infiltration of the thrombi by inflammatory cells. Occasionally fragments of infiltrated thrombi, possibly carrying the noxa, may break off to form pulmonary emboli.

Differential diagnosis has been reviewed by Beerman (1953) and by Hallahan and Klein (1951), with whom we agree that 'the disease is undoubtedly more common than is realized and frequently goes undiagnosed'. Investigation of a patient with WeberChristian panniculitis, therefore, should include a thorough search for signs of bacterial or virus infection, hypersensitivity to bacterial antigens, autoallergic manifestations, pancreatic disease, and disturbances of lipid metabolism. The patient should also undergo prolonged observation with the possibility in mind of the systemic form of the disease whose insidious course has so frequently eluded both diagnosis and treatment.

We wish to thank Dr. L. B. Cole under whose care the patient was admitted, and Dr. A. J. Rook and Dr. G. A. Gresham for their encouragement and advice.

REFERENCE;

Arnold, H. A., and Bainborough, A. R. (1963). Canad. med. ass. J., 89, 1138.

Beerman, H. (1953). Amer. J. med. Sci., 225, 446.

Brill, I. C. (1936). Medical Papers Dedicated to H. A. Christian, pp. 694-704. Waverley Press Inc., Baltimore, U.S.A.

Christian, H. A. (1928). Arch. intern. Med., 42, 338.

Crane, J. T., Aguilar, M. J., and Grimes, O. F. (1955). Amer. J. Surg.. $90,169$.

DeLor, C. J., and Martz, R. W. (1955). Ann. intern. Med., 43, 591.

Fukuoka, Y., Ito, N., and Takeda, Y. (1957). Acta path. jap., 7, (suppl.), 761.

Hallahan, J. D., and Klein, T. (1951). Ann. intern. Med.. 34, 1179.

Hanrahan, F. R. Jr., Ippolito, V. D., and Dilworth, R. W. (1951). Ohio St. med. J., 47, 427.

Hauge, B. N., and Christiansen, T. (1954). Acta med. scand., 150, 193.

Herrington, J. L. Jr., Edwards, W. H., and Grossman, L. A. (1961) Ann. Surg., 154, 949.

Hutt, M. S. R., and Pinniger, J. L. (1956). J. clin. Path., 9, 316.

Jura, V. (1924). Policlinico, Sez. prat., 31, 575.

Kennedy, R. J., and Murphy, L. R. (1949). Amer. J. Med., 6, 672.

Kiernan, P. J., and Burger, H. G. (1960). Med. J. Aust., 1, 966.

Macdonald, H. R. F. (1957). Brit. J. clin. Pract., 11, 264.

Miller, J. L., and Kritzler, R. A. (1943). Arch. Derm., 47, 82.

Mostof, F. K., and Engleman, E. (1947). Arch. Path., 43, 417.

Nakagawa, S., and Takayanagi, N. (1962). Acta path. jap., 12, 259.

Pfeifer, V. (1892). Dtsch. Arch. klin. Med., 50, 438.

Ricci, C., Micheletti, P. C., and Coscia, G. C. (1961). Minerva med. 52, 3725.

Ritama, V., and Krusius, F.-E. (1953). Ann. Med. intern. Fenn., 42, 133. Rogers, C. E., Demetrakopoulos, N. J., and Hyamns, V. (1961). Ann. Surg., 153, 277.

Schoen, I., Reingold, I. M., and Meister, L. (1958). Ann. intern. Med., $49,687$.

Shuman, C. R. (1951). Arch. intern. Med., 87, 669.

Spain, D. M., and Foley, J. M. (1944). Amer. J. Path., 20, 783.

Steinberg, B. (1953). Ibid., 29, 1059.

Tedeschi, C. G., and Botta, G. C. (1962). New Engl. J. Med., 266, 1035.

Ungar, H. (1946). J. Path. Bact., 58, 175.

Weber, F. P. (1925). Brit. J. Derm., 37, 301. 